\title{
IGREJA E TERRITÓRIO, ENTRE O TEMPO, O ESPAÇO E OS CONFLITOS: DISCURSOS E PRÁTICAS SOBRE BELO MONTE
}

\author{
Tânia Nazarena de Oliveira Miranda ${ }^{1}$
}

\begin{abstract}
RESUMO
A implantação do complexo de Belo Monte suscitou manifestações de ordem favoráveis e contrárias ao projeto de desenvolvimento na Amazônia. Vários setores e atores ligados à sociedade civil e governamental se envolveram na formulação de estratégias que permitiram discutir: os modelos de desenvolvimento, as questões ambientais, as alternativas e posturas que resultam em várias manifestações envolvendo o campo e a cidade, com repercussão em nível nacional e internacional. O presente texto apresenta o contexto das contradições referentes às concepções sobre a construção da hidrelétrica de Belo Monte. As questões pertinentes sobre território, identidade, realidade, desenvolvimento e progresso - as quais pontuam os governos, os consórcios, os movimentos sociais e a Igreja Católica - suscitam ampla discussão na sociedade brasileira. Os dados utilizados foram obtidos no levantamento de campo realizado em Altamira entre os agentes de pastorais, comunidade local, Movimento Xingu Vivo para Sempre e lideranças da Prelazia do Xingu. Foram tratados segundo a metodologia qualitativa e quantitativa utilizando a técnica de pesquisa do discurso do sujeito coletivo. À época observou-se a estreita relação da Igreja com movimentos e grupos, que encamparam a luta na região do Xingu. Identificou-se também que não é o todo da Igreja do Xingu que compartilha a resistência ao desenvolvimento e progresso que o estado e consórcio idealizam. Demonstra que há divergências e mudanças internas, na Igreja Católica e nos Movimentos Sociais, e na atual conjuntura as divergências e separações estão em pleno vigor.
\end{abstract}

Palavras-chave: Igreja. Movimentos Sociais. Território. Desenvolvimento.

\section{RÉSUMÉ}

La mise en œuvre du complexe Belo Monte a donné lieu à des manifestations favorables et contraires au projet de développement en Amazonie. Différents secteurs et acteurs liés à la société civile et au gouvernementale se sont impliqués dans la formulation de stratégies qui ont permis de débattre : modèles de développement, enjeux environnementaux, alternatives et attitudes qui se traduisent par diverses manifestations, impliquant le rural et la ville, avec des répercussions au niveau national et international. Au texte et sera présenté ici le contexte des contradictions concernant les conceptions sur la construction de l'hydroélectrique de Belo Monte. A cet effet, seront abordées les questions pertinentes aux discours, développées par les acteurs sociaux impliqués. Il y aura un premier. Les questions pertinentes sur le territoire, l'identité, la réalité, le développement et le progrès - qui ponctuent les gouvernements, les consortiums, les mouvements sociaux et l'Église catholique soulèvent un large débat dans la société brésilienne. Les données utilisées ont été obtenues lors d'une enquête de terrain réalisée à Altamira, auprès d'agents pastoraux, de la communauté locale, du Movimento Xingu Vivo para Sempre et des dirigeants de la Prélature de Xingu. Les données ont été traités selon la méthodologie qualitative et quantitative en utilisant les techniques de recherche sur le discours du sujet collectif, aussi que la recherche bibliographique, documentaire et des entretiens. À l'époque, la relation étroite de l'Église avec les mouvements et les groupes sociaux a été observée, ce qui a conduit à la lutte dans la région de Xingu, en raison de son histoire d'insertion dans le lieu et l'option de défense des droits de l'homme. Il a également été identifié que ce n'est pas l'ensemble de l'Église du Xingu. Cela montre qu'il y a des divergences et des changements internes, dans l'Église

\footnotetext{
${ }^{1}$ Bacharel e Licenciada Plena em Ciências Sociais com ênfase em Antropologia pela Universidade Federal do Pará - UFPA, Especialista em Estudos Culturais da Amazônia - UFPA. Mestra em Ciências da Religião pela Universidade Estadual do Pará UEPA. Doutora pelo Programa de Pós Graduação em Sociologia e Antropologia (PPGSA - UFPA). ORCID:https://orcid.org/0000-0002-8476-6649E-mail: taniamiranda18@ yahoo.com.br.
} 
catholique et dans les mouvements sociaux, et dans la conjoncture actuelle les divergences et les séparations sont en pleine vigueur.

Mots-clés: Église. Mouvements sociaux. Territoire. Développement.

Data de submissão: 07.10 .2020

Data de aprovação: 18.10 .2020

\section{INTRODUÇÃO}

A proposição concernente a Igreja e território: entre o tempo, o espaço e os conflitos. Discursos e práticas sobre Belo Monte ${ }^{2}$, situa a Igreja Católica no território brasileiro, desde a colônia aos dias atuais, atravessando as suas ações pelo tempo na região do Xingu. Esta temática demonstra que os caminhos percorridos levaram a instituição citada a optar por um tempo de Igreja que se contrapõe e resiste à instalação do sistema hidrelétrico de engenharia Belo Monte no rio Xingu - sistema este situado em Altamira, no sudoeste do estado do Pará. Compreende também que o sistema hidrelétrico de Belo Monte seguiu a perspectiva dos Grandes Projetos, planejados para o "progresso e desenvolvimento" na Amazônia, representados pela Transamazônica, a Ferrovia de Aço, a Usina de Itaipu, Usina de Tucuruí, o projeto Carajás, iniciativas construídas no contexto de crise internacional do petróleo ocorridas no início da década de setenta (1970), quando à defesa do pensamento da construção de hidrelétricas a evidenciava como única alternativa para o alcance de metas estabelecidas pelas políticas desenvolvimentistas. Evidencia ainda que a Igreja do Xingu em conjunto com os movimentos sociais, intelectuais orgânicos, sindicatos e partidos de esquerda elaboraram concepções sobre uma variedade de temas que influenciaram significativamente a prática social de muitos militantes que se expressam no pensamento sobre progresso e desenvolvimento para a região.

A presente discussão segue em primeira instância o tempo de Igreja e sua atuação no espaço, lugar e território vistos a partir da análise do discurso e sua relação com o processo histórico de ocupação evangelizadora da Amazônia, resultantes da associação com o estado português, ora desvinculada das ações das relações estatais. A abordagem de uso do território será a referência de objeto de análise social, pois no decorrer da revisão histórica foi possível apreender o território amazônico como apropriado e cada vez mais dependente de decisões externas. O uso do território analisado segundo os autores, Santos (1994); Rodrigues (2010) e Silveira (2011) têm como premissa as noções de utilização do lugar, do espaço em competitividade, no qual os atores são reordenados de acordo com o tempo e objetivos do uso do território.

A proposição fomenta a observação de que a compreensão específica da realidade empreendida pela Igreja do Xingu ${ }^{3}$ a coloca como protagonista das ações em defesa dos Direitos Humanos junto às comunidades de Altamira e/ou regiões pastorais de atendimento desta Prelazia, aos povos indígenas, aos quilombolas e às mulheres. As informações obtidas na pesquisa dão conta de que esta região do Xingu chamou a atenção devido à acontecimentos como o assassinato de trabalhadores rurais em 1982; a Greve dos canavieiros - evento ocorrido em 1983, causador não só da prisão do bispo e de duas lideranças de Pacoval, como também na tentativa de assassinato ao bispo, da liderança da CPT e do padre Tore, assim

\footnotetext{
${ }^{2} \mathrm{O}$ presente texto tem origem na pesquisa que resultou na dissertação de mestrado em Ciências da Religião, defendida em 2013 no Programa de Pós-graduação em Ciências da Religião (PPGCR) da Universidade do Estado do Pará (UEPA), Linha de Pesquisa: Movimentos e Instituições Religiosas na Amazônia, sob a orientação da Prof $^{a}$ Dr $^{a}$ Maria Marize Duarte.

${ }^{3}$ Em nível Regional Norte II a Igreja Indígena é assim reconhecida alcançando a toda a Região do Xingu demarcação do eclesiástica e demarcação administrativa do Estado.
} 
como na morte do referido padre, em 1983; o caso dos meninos emasculados de Altamira; o I Encontro dos Povos Indígenas em 1989 - com cenas de manifestação dos índios contra Kararaô $^{4}$; o assassinato, em 2005, da Missionária Dorothy Stang; o II Encontro dos Povos Indígenas, em 2008. Diante destes acontecimentos e eventos, considera-se que nos últimos anos, a Igreja citada constitui uma das vozes mais contundentes em resistência a construção de Belo Monte.

Adotou-se como base de referência metodológica o discurso do sujeito coletivo eleito como técnica para análise. Inicialmente para a composição da análise foi realizado: a) as referências bibliográficas, a fim de aprofundar o significado dos discursos referentes às argumentações favoráveis e resistentes ao projeto Belo Monte, com particular leitura aos debates sobre as categorias de análises pertinentes ao objeto de estudo.

Considerando o tempo da pesquisa e as reais transformações no território com a efetivação da Hidrelétrica de Belo Monte, assim como das mudanças eclesiásticas em sua administração e sucessivamente das posições de pensamento e ação pastoral, situa-se este trabalho no posicionamento da Igreja Católica, movimentos sociais atuantes na região do Xingu em resistência a construção da Hidrelétrica de Belo Monte, pautado no conhecimento dos direitos ambientais, étnicos e territoriais. E ainda as previsões dessas entidades quanto aos impactos destrutivos a região.

Os discursos contrários ao projeto Belo Monte e os favoráveis ao mesmo projeto expõe os grupos à época do início da construção da hidrelétrica. As entrevistas foram realizadas em pesquisa de campo, no entanto foram além das motivações acadêmicas, pois abrange o envolvimento de mais de vinte anos desta pesquisadora nas atividades, não apresentou apenas caráter profissional, mas também caráter militante que, aliás, permitiu a percepção acerca das várias articulações, mobilizações e espaços de formação política.

\section{FUNDAMENTAÇÃO TEÓRICA}

\subsection{IGREJA E TERRITÓRIO: ENTRE O TEMPO, O ESPAÇO E OS CONFLITOS}

Para efeito de compreensão quanto ao espaço e lugar, se faz importante diferenciar as categorias: território, territorialidade e desterritorialização. $\mathrm{O}$ espaço pode ser definido como "abstrato e genérico e o lugar concreto e abstrato". (LITTLE, 2002, p. 10). A identificação dos lugares sagrados por um grupo determinado representa uma das formas mais importantes de dotar um espaço com sentimento e significado (DELÓRIA, 1994 apud LITTLE, 2002). A noção de lugar também se expressa em valores diferenciados que um grupo social atribui aos diferentes aspectos do seu ambiente. O pertencimento a um lugar refere-se a grupos que se originaram sejam eles primeiros ou não. Tanto os povos indígenas quanto os grupos que historicamente se assentaram numa área, independente do processo, contam com esse lugar como o seu lugar verdadeiro, seu lar, sua casa, seu território. A definição de lugar verdadeiro se dá em especial pela relação com o espaço físico. Para Little (2002, p. 9) "o sentimento de pertença pode se ampliar à medida que assume-se a identidade de um grupo que passa, entre outras coisas, pela relação com os territórios construídos com base na experiência, história e nas suas respectivas cosmografias". E sua continuidade permanece viva nos bastidores da memória coletiva.

Ainda Little (2012, p. 10) considera que "o território grupal está ligado a uma história cultural", ou seja, cada grupo constrói sua memória coletiva por fatores novos e circunstanciais e movimentos diferenciados. A memória coletiva sacraliza o lugar mesmo que tenha partido do caos. Sobre o lugar, alguns autores afirmam "que uma ligação emocional é

\footnotetext{
${ }^{4}$ Na língua Kaiapó significa - um grito de guerra. Em 1989 o governo se manifesta para construir a hidrelétrica que era KARARAÔ, mas então eles mudaram para Belo Monte.
} 
criada e mantida através da edificação do lugar sagrado". (TUAN, 1979 e 1980 apud ROSENDAHL, 2005, p. 4). E ainda a posse do território é seguida de um ritual que simboliza $\mathrm{o}$ ato da criação. A comunidade consagra o lugar e o reconhece como seu. O processo no Xingu resulta neste sentido de ocupação, sacralização e permanência na história construída pelos religiosos, missionários e aventureiros e ainda pela cobiça de novos empreendimentos.

No campo das ciências sociais, a ideia de território está vinculada à gestão de uma determinada área. Vincula-se a ideia tanto de poder público estatal quando a do poder das grandes empresas, que estendem seus tentáculos por grandes áreas territoriais, mas ignoram as fronteiras políticas. Algumas empresas em determinados locais são tão importantes que determinam a distribuição do espaço muito mais do que o Estado-nação. No período de construção da Hidrelétrica de Belo Monte em Altamira, toda e qualquer manifestação de precariedade no campo da educação e da saúde, a população recorre ao Consórcio Norte Energia como se o consórcio fosse o Estado. Este processo acompanha aquilo que se denomina de globalização, de mundialização da economia que são estudadas por autores como: Santos (1994); Santos (2002) e Rodrigues (2010).

Para Santos (1994), território e globalização partem da motivação de competitividade na busca de maior produtividade que depende das condições oferecidas nos lugares de produção, de circulação e de consumo. Para Rodrigues (2010), Belo Monte é um caso exemplar de território usado com tendências a serem funcionalizados, segundo o processo de regularização institucional e corporativo e, neste sentido, o Brasil, por seus governantes, é um espaço permissivo.

Percebe-se que em cada período e em cada tempo de Igreja há necessariamente a presença simultânea de heranças do passado, de elementos do futuro, mas o discurso se coloca de acordo com o pensamento sobre desenvolvimento do local. Observa-se também que o território preexistente condiciona e reflete os impactos da ação dos agentes propagadores da inovação, assim, não é surpreendente dizer que a organização do espaço amazônico aparece imergida em contextos socioespaciais, ora como protagonista do arranjo espacial momentânea, ora como coadjuvante em uma dada época específica na qual o arranjo se transformou.

Mas a realidade em Altamira à época da pesquisa e, para tanto na atualidade, é resultado de um processo iniciado ainda no período militar que defendia o discurso de desenvolvimento e progresso na Amazônia ou mais atualizado na nomenclatura de neodesenvolvimentismo que se assemelha, segundo Cândido Grzybowski (2010), ao período de Juscelino Kubitschek (1956 e 1961), ou seja, o Estado presta-se antes de tudo ao fortalecimento do capital privado. Com o governo de Juscelino, se deu a formação do tripé Estado, empresas estrangeiras e empresas nacionais. O papel do Estado é o de responder às demandas de infraestrutura, de energia e logística para atender aos interesses do capital privado nacional e transnacional. Assim o presidente Juscelino procurou realizar o seu modelo de desenvolvimento, que na atualidade é o que propõe o atual modelo econômico, através do Programa de Aceleração da Economia (PAC), acelerar sem desenvolver.

Este modelo de desenvolvimento tem suas explicações baseadas em que,

[...] é um processo social, global e dialético, consequência do desenvolvimento do capitalismo industrial, cujo mecanismo básico consiste: para engendrar e sustentar seu progresso científico e o seu crescente bem-estar: em criar um centro ou uma metrópole e uma sucursal onde se instaura a dependência, o estancamento econômico, os desequilíbrios sociais e as tensões políticas sem saídas autônomas. [...] O desenvolvimento a partir dessa teoria não tende sair do subdesenvolvimento, mas a manter a relação de dependência. (ANDRADE FILHO, 1982, p. 20). 
O desenvolvimento e progresso, neste sentido, é um problema político, consequência do sistema capitalista, onde há um espaço que absorve a matéria-prima e outro que fornece a ciência e a técnica, por isso o investimento em rodovias, ferrovias e hidrovias. Não só Belo Monte, mas as hidrelétricas nascem com intencionalidade mundial e nacional. Assim, de acordo com os acontecimentos, Belo Monte foi concebida segundo as concepções militares, principalmente a partir de 1975, momento em que houve a responsabilidade de elaborar o projeto básico de Engenharia e os Estudos de Impacto Ambiental - EIA/Rima -, ou seja, os primeiros estudos sobre como aproveitar o rio Xingu para produzir eletricidade. Em quatro anos de estudo, o Consórcio Nacional de Engenheiros Consultores (CNEC) chegou à conclusão de que seria possível construir cinco (05) usinas hidrelétricas no rio Xingu. Prevista para iniciar em 1993 a primeira hidrelétrica Kararaô, com produção de um pouco mais de 11.00 MW, representando assim muita eletricidade com capacidade de sustentar as fábricas de São Paulo e Rio de Janeiro (PONTES, 2010).

Este processo inicial com o passar do tempo se modifica em questão de condicionamentos colocados em pauta por meio de estudos, debates e posicionamentos de grupos de esquerda e ainda devido a posição da Igreja, representada pela presença de padres, freiras, indígenas, agentes de pastorais, sindicatos e partidos de esquerda. Em 1989, no I Encontro dos Povos Indígenas, encontro organizado para este momento, a batalha foi vencida, motivado pela pressão da organização e "pelo cancelamento do Banco Interamericano de Desenvolvimento (BIRD) houve o cancelamento de todo o financiamento para as hidrelétricas na Amazônia". (PINTO, 2002, p. 30-31). O projeto foi arquivado, porém não esquecido.

A Prelazia do Xingu acompanha o processo de desenvolvimento da sua própria região até os dias atuais e se coloca resistente à construção de Belo Monte, isto se deve, segundo esta pesquisa, a sua história de inserção na região fomentada por meio do contínuo esforço em dar visibilidade às situações ocorridas nas localidades, haja vista, a mesma cumpre o papel de incentivadora e promotora de debate em universidades, na mídia e também entre as autoridades. Afirma-se, então, que a partir de tais ações desta instituição católica na região pontua conceitos e teorias. Demonstra-se ainda que a Igreja do Xingu contribuiu no processo de formação dos movimentos sociais, entre eles o reconhecido como Movimento Xingu Vivo para Sempre (MXVPS). Percebe-se a construção do discurso de atuação da Igreja do Xingu evidenciando a gênese, as concepções acerca da contraposição à Belo Monte e suas influências no pensamento e lutas desenvolvidas pelos movimentos em volta do Xingu.

Sobre os discursos e representações de Belo Monte, tratou-se pela perspectiva do Discurso do Sujeito Coletivo (DSC) que em síntese "é o sujeito que fala - ou o discurso coletivo representado em um sujeito" (LEFEVRE, 2000, p. 3). O depoimento é singular - na primeira pessoa - mas sempre nesta percepção de encontrar o efeito da opinião do coletivo em um único sujeito de discurso. O DSC, de acordo com Lefevre (2000), tem o arcabouço na Teoria das Representações Sociais que, por sua vez, elenca uma série de operações sobre a matéria-prima de depoimentos coletados em pesquisas empíricas de opinião por meio de questões abertas, que se concretiza em depoimentos coletivos vinculados a depoimentos individuais.

$\mathrm{O}$ rio Xingu revela-se como símbolo de um novo movimento, em que a comunidade está exposta, pelos impactos que certamente ocorrerão, em função da construção da hidrelétrica. Nas entrevistas realizadas e nas manifestações expressas em relação à Barragem, esta é identificada como uma ameaça ao modo de vida de vários grupos do Xingu. Em contraposição a este novo tipo de desenvolvimento, há uma rede de resistências tecidas por inúmeros grupos sociais, com a particular presença de protagonistas pertencentes à Igreja do Xingu, que ao longo de sua existência, neste espaço eclesiástico, se colocam em favor da causa das populações atingidas pelos grandes projetos na Amazônia. 


\section{IGREJA DO XINGU TERRITÓRIO ECLESIÁSTICO: CENÁRIO DE LUTAS E CONQUISTAS}

Na Amazônia brasileira, quando se aprecia a diversidade e a complexidade, percebe-se claramente a presença de mecanismos de dependência acumulados e reproduzidos no curso de um período recente (a partir de fins do século XIX), a presença de tais mecanismos impõe conflitos marcados por enfrentamentos de políticas de colonização posta em operação a partir dos anos de 1950, durante a ditadura militar. O programa de Integração Nacional das regiões norte e nordeste do Brasil, com perspectiva de mudar a realidade das desigualdades regionais do país. Assim, o "modelo desenvolvimento" que envolveu uma grande parte da Amazônia brasileira chega a Região do Xingu, decolando situações de muitos conflitos, mas também de resistências, mobilizações interligadas entre Igreja Católica, movimentos sociais, partidos de esquerda, intelectuais orgânicos, entre outros em defesa do território, do meio ambiente e das populações tradicionais.

A Prelazia do Xingu, com sede em Altamira, percebe-se na cidade os vários espaços como contribuição da Congregação Preciosíssimo Sangue de Cristo (CPSC) que recebeu a estrutura seguindo a lógica de assistência ou das necessidades existente nas dioceses e Prelazias da região, mas não se limitou a sua sede da Prelazia, está em processo de extensão pastoral. O elemento estrangeiro arrecada em seu país de origem, geralmente europeu, recursos para construir infraestrutura para atendimento da comunidade. A exemplo deste elemento de condições físicas em Altamira, a CPSC construiu: o hospital São Rafael em 1968, a $1^{\text {a }}$ Escola de nível secundário Instituto Maria Matias em 1976, O Cine João XXIII na década de 60 e contribuiu com equipamentos vindos da Alemanha para a construção da $1^{\text {a }}$ Cerâmica de São Sebastião (UMBUZEIRO, 2012).

Assim, as dioceses e as Prelazias, para suprirem o atendimento à comunidade em seus municípios-sede, acabam assumindo papéis que obrigatoriamente seriam do Estado, ou seja, na ausência destas organizações, assumem este papel. As demandas crescem com os movimentos migratórios que geralmente são acompanhados por pesados investimentos em infraestrutura, mudando de forma contundente as relações fundiárias no país, no entanto, a história tem mostrado que os pesados investimentos sempre ficam inacabados, deixando em situação de calamidade após sua saída.

O território eclesiástico do Xingu é delimitado do sul ao norte do estado. A Prelazia do Xingu representa um campo de observação dos processos de transformações territoriais dentro do território eclesiástico. O sentimento regional se desenvolve ou se atenua com a intensidade de evangelização, se desenvolve também com a identidade que acentuaram os conflitos e sucessivamente com as transformações em volta da Terra do Meio, assim chamada por se localizar entre dois rios importantes da Bacia Amazônica, Tapajós e Xingu, região localizada no meio do Pará.

As ações da Prelazia do Xingu que historicamente estão presentes em seus documentos - com marcas de denúncias e pregações - objetivam a preservação de sua territorialidade "compreendida aqui e marcada pelo movimento de apropriação e reprodução das relações sociais". (CARA, 1994, p. 262-263). Tais concepções estão estritamente vinculadas à cotidianidade e são vistas pelas múltiplas dimensões dos grupos sociais, nascidos e fortalecidos sob a identidade católica no Xingu, que envolvem processos marcados pela identidade e cultura religiosa. Os missionários consideram o Xingu como um lugar sagrado, pois se estabeleceram neste espaço a partir da participação e da memória histórica, no tempo e no espaço da região. Certamente, "o território identitário religioso não é apenas ritual e simbólico ele é também o local de práticas ativas e atuais, por intermédio, das quais se afirmam e vivem as identidades". (ROSENDAHL, 2005, p. 5). 
Considerando a diocese e a Prelazia como unidades político-administrativas que atuam no processo de regulação das ações de controle pastoral, em si, observa-se que estas constituem uma unidade de representação do território de aproximação entre o regional e o universal, do cotidiano constituído no local e das ações de escala no mundo. Percebe-se no Xingu que o grau de participação da igreja na vida da comunidade ao longo de sua permanência, no qual foi capaz de criar símbolos e representações, articulam através do meio ambiente a sua própria história. Verifica-se, portanto, uma identidade espacial e comunitária onde os conceitos de territorialidade e identidade, ou seja, "a qualidade subjetiva do grupo social ou do indivíduo que lhe permite, com base em imagens, representações e projetos, tomar consciência de seu espaço de vida". (RAFFESTTIN, 1977, p. 130 apud CARA, 1994, p. 262). O local, o regional, o nacional podem ser analisados segundo a conceituação de territorialidade como "continuidade e descontinuidade espacial que voluntariamente se constrói a identidade, o sentido de pertença, de tomada de consciência no local em que habita, convive, almeja, sacraliza o seu ambiente" (CARA, 1994, p. 262-263). Logo, a construção da identidade territorial do Xingu, segundo seus objetivos e ações, formaram uma territorialidade particular de movimentos em favor das minorias existentes no local, mas em especial, a partir de um tempo de igreja considerada "profética".

As concepções proféticas resultam de um processo de formação de lideranças religiosas e leigas, construídas pela Igreja a partir da década de setenta (1970) e fundamentadas na teologia da libertação - movimento que desenvolveu "em sua prática religiosa e política a construção de uma utopia na América Latina e no Brasil". (SCHERERWARREN, 1993, p. 27-28) e, assim, "contribuiu direta ou indiretamente para uma nova compreensão da realidade brasileira". (IOKOI, 1996, p. 67). Esta Igreja proporciona, a partir da década de oitenta (1980), mecanismos de apoio à dinâmica de lutas e resistências de conteúdos que visam ações transformadoras à sociedade e que "serviu de apoio e expressão da fala e da luta dos pobres da cidade e do campo". (MARTINS, 1991, p. 29).

Quanto à gestão eclesiástica vivenciada pela Igreja Católica, faz-se diferenciada da lógica dividida pelo estado - nação, IBGE ou região academicamente reconhecida. Por meio de decisões eclesiásticas, em particular no Brasil, a Conferência Nacional dos Bispos do Brasil (CNBB), se configura em divisões regionais, sendo estes espaços denominados de Regional Norte II. A pesquisa fez o recorte espacial demarcado pela divisão da territorialidade católica identificada em sua origem pela distribuição de suas unidades, em diocesanas e prelatícias, associadas em suas atividades pastorais e suas reflexões nas dimensões espaciais desde os primeiros missionários chegados ao Xingu.

Esta divisão eclesiástica não segue a divisão do Estado-nação que se dá por meio de acordos diplomáticos delimitados juridicamente, mas representa uma abstração instituída politicamente e reconhecida legalmente pela escala nacional e, ao mesmo tempo, é subordinada ao controle da legislação internacional. Assim são fixadas as normas, os regulamentos e os obstáculos para proteger o território e suas melhorias a partir de medidas político-administrativas outorgadas. Devido ao tempo de colonização que ampliou o espaço eclesiástico por meio de "ocupações, invasões, os conflitos e ambição dos portugueses, pois apesar da bandeira dos portugueses em editar a fé, mas por excelência seus objetivos eram comerciais." (FRAGOSO, 1992, p. 181-184).

\footnotetext{
5 No Primeiro Testamento (Bíblia Cristã), os profetas foram referência, pois não aceitavam uma sociedade injusta, mas lutavam pelo cumprimento da aliança com Moisés e suas Leis. Condenavam especialmente a opressão social, ou seja, não admitiam que os mais ricos explorassem os que nada tinham, (Am 4, 1). Também pregavam contra a bajulação aos ricos, usada para conseguir qualquer favor (Am 6, 1). Ao fazer referência sobre o assunto, Macedo (1986, p. 59) diz que: "O tom profético da Igreja Católica se constituiu como uma das poucas instituições nacionais capazes de enfrentar o Estado".
} 
No Xingu, segundo levantamento histórico, já havia todo um processo de colonização e sucessivamente de evangelização, pois, logo depois da expulsão dos holandeses, a partir de 1636, a Companhia de Jesus iniciou a catequese e a ocupação territorial, sua permanência durou até 1760 implantando no baixo e médio Xingu centros de aldeamentos. A própria Companhia de Jesus ensinou ofícios aos índios para a construção de seus colégios e suas Igrejas. (ACEVEDO, 2010, p. 4).

Nascida juridicamente para atender as determinações da Santa Sé, a Prelazia do Xingu foi confiada aos cuidados da Congregação dos Missionários do Preciosíssimo Sangue (CPPS) de origem austríaca. No período de 1935 a 1948 a Prelazia foi governada por administradores apostólicos: Dom Amando Bahlmann, OFM (1935) e Padre Clemente Geiger, CPPS (1935-1948). $1^{\circ}$ Bispo D. Clemente Geizer (1948 - 1971) e $2^{\circ}$ Bispo D. Eurico Kräutler $\left(1971\right.$ - 1981). O $3^{\circ}$ prelado estava sob a responsabilidade de Dom Erwin Kräutler, no qual foi presidente do Conselho Indígena Missionário (CIMI) de 1983-1991, de 2006 aos dias atuais do CIMI. Dom Erwin Kräutler, durante oito anos, foi o responsável nacionalmente pela Dimensão Missionária da Conferência Nacional dos Bispos do Brasil (CNBB), atualmente é bispo prelado emérito do Xingu, e vice-presidente da REDE Eclesial PanAmazônica (REPAM).

A Rede Eclesial Pan-Amazônica (REPAM) foi fundada em setembro de 2014, em Brasília (DF). Entidades fundadoras: Conselho Episcopal Latino-americano (CELAM), Conferência Nacional dos Bispos do Brasil (CNBB), Secretariado da América Latina e Caribe de Caritas (SELACC), Confederação Latino-americana e Caribenha de Religiosos e Religiosas (CLAR). O nascimento se dá a partir de uma provocação da V Conferência Geral do Episcopado Latino-americano e do Caribe, em Aparecida (SP), em que sugeriu "[...] Estabelecer entre as Igrejas locais de diversos países sul-americanos, que estão na bacia amazônica, uma pastoral de conjunto com prioridades diferenciadas para criar um modelo de desenvolvimento que privilegie os pobres e sirva ao bem comum". (DOCUMENTO DE APARECIDA, 2007, (475), p. 73).

Desde então se inicia um diálogo de maturação até se criar a REPAM que abraçasse a realidade da Pan-Amazônia que envolve os nove países que têm a floresta amazônica em seu território: Brasil, Bolívia, Peru, Equador, Colômbia, Venezuela, Guiana, Guiana Francesa e Suriname.

Em 2012, contando os anos do $2^{\circ}$ bispado e do $3^{\circ}$ bispado totalizam um pouco mais de setenta (70) anos no Xingu, significa dizer que a Prelazia acompanhou as principais mudanças referentes ao lugar. Em 2015, por limite de idade, D. Erwin Kräutler renunciou deixado a vacância para um novo episcopado e novos "espíritos" na Igreja. A Prelazia até o ano de 2019, era o maior Vicariato Brasileiro, em termos de extensão territorial que abrangia uma área de $368.086 \mathrm{~km}^{2}$, e a Prelazia do Xingu era responsável pelos espaços abaixo com sede em Altamira. 
Tabela 1 - Aspectos demográficos dos municípios que compõem à Prelazia do Xingu

\begin{tabular}{llccc}
\hline MUNICIPIO & $\begin{array}{l}\text { AREA } \\
(\mathrm{km} 2)\end{array}$ & $\begin{array}{l}\text { POPULAÇAO } \\
\text { RURAL }\end{array}$ & $\begin{array}{l}\text { POPULAÇAO } \\
\text { URBANA }\end{array}$ & $\begin{array}{l}\text { POPULAÇÃO } \\
\text { TOTAL }\end{array}$ \\
\hline Altamira* & 159.533 & 14.983 & 84.092 & 99.075 \\
Anapu & 11.895 & 10.710 & 9.833 & 20.543 \\
Brasil Novo & 6.303 & 6.899 & 8.791 & 15.690 \\
Gurupá & 8.570 & 19.482 & 9.580 & 29.062 \\
Medicilândia & 8.272 & 17.769 & 9.599 & 27.368 \\
Placas & 7.173 & 19.080 & 4.854 & 23.934 \\
Porto de Moz & 17.423 & 19.373 & 14.583 & 33.956 \\
Senador José Porfírio & 14.419 & 6.470 & 6.575 & 13.045 \\
Uruará & 10.791 & 20.359 & 24.470 & 44.829 \\
Vitória do Xingu* & 4.751 & 8.069 & 5.362 & 13.431 \\
\multicolumn{1}{c}{ TOTAL } & $\mathbf{2 8 0 . 6 7 8}$ & $\mathbf{1 4 3 . 1 9 4}$ & $\mathbf{1 7 7 . 7 3 9}$ & $\mathbf{3 2 0 . 9 3 3}$ \\
\hline
\end{tabular}

Fonte: IBGE, 2010.

Em 06 de novembro de 2019, com a reestruturação eclesiástica do Regional Norte 2, o Papa Francisco elevou a Prelazia do Xingu à categoria de Diocese do Xingu com sede em Altamira-PA. Na ocasião, criou a Prelazia do Alto Xingu com sede em Tucumã-PA. Para a Diocese do Xingu, foi nomeado como primeiro Bispo Diocesano: Dom Frei João Muniz Alves, OFM. A instalação da Diocese e posse do Bispo ocorre em 1\%/02/2020, em Altamira. Quarto e atual Bispo Prelado: Dom João Muniz Alves, OFM (2016-2019). Continua sendo o maior Vicariato Brasileiro, o mapa abaixo demonstra sua extensão de norte a sul do estado do Pará. Além da extensão, o trabalho pastoral realiza-se na área conhecida como Terra do Meio. Abaixo a extensão do território de norte a sul do Pará.

Mapa 1 - Extensão territorial da Diocese do Xingu
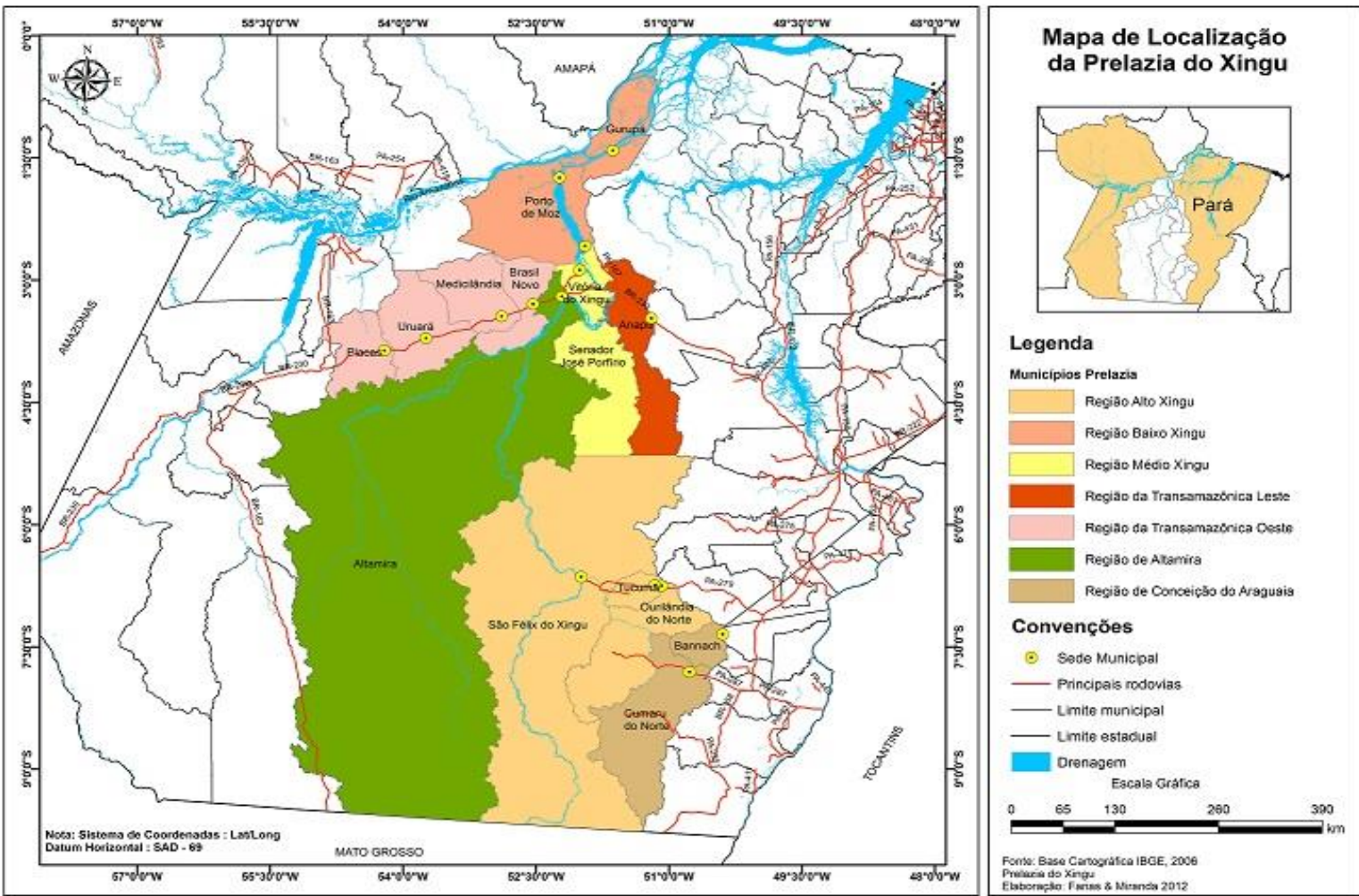

Fonte: Adaptado da Prelazia do Xingu pelo Maicon Farias, 2012/2020. 
A Terra do Meio é uma área de floresta tropical Amazônica relativamente intacta que se estende por 8,3 milhões de hectares entre os Rios Xingu, Tapajós, Curuá, Xipaia e Iriri. A terra do Meio faz divisa ao Norte com os territórios indígenas Arara, Kararaô e Cachoeira Seca do Iriri; ao Oeste com a Estrada Cuiabá-Santarém; ao Leste com o Rio Xingu; ao Sul com as terras indígenas Kayapó. Pelos menos dois territórios indígenas (Xipaia e Curuá) estão dentro da área, mas ainda não foram demarcados ou formalmente reconhecidos pelo Governo Brasileiro. (PONTES; BELTRÃO, 2005). Em 2001 emergiu um conflito na região da Terra do Meio na área indígena dos Apiterewa-Parakanã. Esta área indígena foi regularizada em 1992 com uma extensão de 980.000 hectares. Apesar disso, o INCRA criou um assentamento (São Francisco) dentro da área e os madeireiros há anos vêm explorando sistematicamente o mogno nos limites das terras dos (Apiterewa-Parakanã.). Quando se fala em Terras Indígenas homologadas, delimitadas e identificadas, localizadas na região do Médio Xingu estão aquelas com a existência da população de 8.450 denominadas de Paquisamba, Boa Vista, Laranjal, Cachoeira Seca, Arara do Maia, Araweté, Koatinemo, Kararaô, Baú - Mekrãgnoti - Kayapó Badjonkore, Kuruaya, Parnará, Apyterea, Xipaya, Trincheira - Bacajá-Tukum.

A Prelazia do Alto Xingu é formada pelos municípios de Tucumã (Sede da Prelazia), São Félix do Xingu, Ourilândia do Norte, Bannach, Cumaru do Norte (pertenciam a Diocese de Conceição do Araguaia) e Água Azul do Norte (pertenciam a Diocese de Marabá). A Prelazia possui 4 Paróquias: Paróquia Nossa Senhora Aparecida (Catedral Prelatícia, em Tucumã (Pará), Paróquia Santa Rita de Cássia, em Ourilândia do Norte, Paróquia São Félix, em São Félix do Xingu.

Com base nas concepções prioritárias de defesa dos direitos humanos, compromisso com a realidade local, ressalta-se também que a Prelazia do Xingu acompanha o processo de desenvolvimento da sua própria região e se colocava resistente à construção da Usina Hidrelétrica Belo Monte, colocando em pauta um grande debate na sociedade brasileira que ultrapassou os limites do local e se configurou em debates e intervenções internacionais. Isto se deve, segundo nosso entendimento, a sua história de inserção na região fomentada por meio do contínuo esforço em dar visibilidade às situações ocorridas nas localidades, haja vista, a mesma cumpre o papel de promotora de debate em universidades, na mídia e também entre as autoridades. Isso se configura até os dias atuais. Demonstra-se ainda que a Igreja do Xingu contribuiu no processo de formação dos movimentos sociais entre eles o que é reconhecido como Movimento Xingu Vivo para Sempre (MXVPS). À época, se evidenciou veementemente em conjunto com a Igreja do Xingu, principal presença e articulação nas lutas desenvolvidas pelos movimentos em volta do Xingu. Afirma-se, então, que a partir de tais ações desta instituição católica na região pontuou-se conceitos e teorias.

Autores como Lefèvre e Lefèvre (2006, 2002) e Brandão (1996), são os teóricos que evidenciam o discurso social em articulação com suas representações sociais da ação coletiva em "conexões individuais construídas pelo sujeito em sua interação com a realidade social, do mesmo modo que a realidade social constitui-se da multiplicidade de experiências individuais". (AVANTARA; VESCE, 2008, p. 6). Afirma-se, por conseguinte, com a adoção da tese de tais teóricos, que as representações sociais abordadas em relação ao Xingu, situamse entre o particular e o universal. Dentro da temática abordada é demonstrado que as observações em relação às opiniões e às discussões acerca das questões sobre Belo Monte foram tratadas pelos entrevistados como próprias dos sujeitos da pesquisa. $\mathrm{O}$ trabalho a partir da técnica do discurso do sujeito coletivo permitiu compreender que as ideias e os posicionamentos não se centralizam sobre determinado tema, mas traduzem reconstruções e significados, pelas relações interpessoais ampliadas e as relações sociais (AVANTARA; VESCE, 2008). 
Portanto, o discurso do sujeito coletivo junto às ações coletivas são os principais pontos para relacionar os conceitos de território e territorialidade com as perspectivas de confiança ao modelo de desenvolvimento sustentado por gestores oficiais enquanto processo planificado para superar o atraso especialmente nas décadas de 1980 e 1990. As entrevistas foram obtidas no período de estadia em Altamira.

Considerando as representações sociais, as mesmas entendidas como "a expressão do pensar ou achar determinada população sobre determinado tema. Este pensar por sua vez, pode se manifestar, dentre outros modos, através do conjunto de discursos verbais emitidos por pessoas dessa população". (LEFÈVRE; LEFÈVRE, 2000, p. 3).

\section{ALTAMIRA: UM CONTEXTO E UMA HISTÓRIA DOS ACORDOS DE DEPENDÊNCIA}

Em sua dimensão territorial, Altamira possui uma área de 159695,938 km², o que o torna o maior município do Brasil e o terceiro maior do mundo. Os seus limites estão ao Norte - Vitória do Xingu, Brasil Novo, Medicilândia, Uruará, Placas e Rurópolis; ao Leste Senador José Porfírio, São Félix do Xingu e Vitória do Xingu; ao Sul - estado do Mato Grosso; a Oeste - Itaituba, Trairão e Novo Progresso. Altamira é também região de fronteira.

Muitos processos em Altamira mudaram o cenário da cidade, tem-se como exemplo: a construção das primeiras estradas amazônicas - Belém-Brasília, Transamazônica, CuiabáSantarém, que nos anos sessenta e setenta foram construídas com a função de acesso à Região Norte para colonos, garimpeiros, fazendeiros, comerciantes e grandes empresas, procedentes de outras regiões de dentro e de fora do país. As ações dos governos militares com o interesse de implantar múltiplos projetos de desenvolvimento nas regiões, tais como: Zona Franca de Manaus, Grande Carajás, a construção de hidrelétricas Balbina, Samuel e Tucuruí no estado do Pará. (LITTLE, 2002, p. 12). As migrações que detém como tendência a permanência daquelas que vieram com suas famílias e se tornam cidadãos altamirenses.

Na região do Xingu, a abertura da Transamazônica é considerada um marco histórico como muitas mudanças na década de setenta (1970). Trouxe para a cidade de Altamira o presidente militar, Emílio Garrastazu Médici, que viajou para o Xingu com o objetivo de abrir oficialmente os trabalhos da construção da Transamazônica, que liga Belém a Porto Velho, passando pela selva virgem da Amazônia. Os reais investimentos estavam na descoberta de riquíssimos recursos em ouro, diamantes, ferro, madeira e outras riquezas presentes na Amazônia. A rodovia Transamazônica (BR 230), ao ser construída, cortou o território de inúmeros povos indígenas e nessa região está situada a maioria das terras indígenas que se encontram no estado do Pará (CIMI, 2010, p. 137). O acesso à terra foi a principal motivação deste processo de migração, objetivando melhores condições de vida, partindo de várias partes do país no sentido da Transamazônica.

É no município de Altamira que se inicia a "volta grande do Xingu", trecho sinuoso e cheio de cachoeiras do Rio Xingu onde, no final do trecho, será construída a Hidrelétrica de Belo Monte. Essa hidrelétrica, com capacidade de $11.182 \mathrm{MW}$, será a terceira maior do mundo, após Três Gargantas, na China, e Itaipu, entre o Brasil e Paraguai, inundará cerca de $400 \mathrm{~km}^{2}$, principalmente nos municípios de Vitória do Xingu e a própria cidade de Altamira. A intenção de construção de hidrelétricas no Xingu teve início - em 1975 - em pleno regime ditatorial que apresentava como base o discurso do desenvolvimento e do progresso na região. A Eletronorte realizou estudos de aproveitamento do rio Xingu para produzir eletricidade e, no mesmo ano, contratou a firma Consórcio Nacional de Engenheiros Consultores (CNEC), pertencente à Empresa Camargo Correa, para pesquisar onde poderia construir as hidrelétricas nos rios Xingu e Iriri. Em 1979, o CNEC finalizou os estudos e na época concluiu que seria possível construir cinco (05) hidrelétricas nos rios Xingu e Iriri. A primeira Hidrelétrica 
estava marcada para iniciar a construção em 1993, junto com esta seria construída a barragem de Juruá, cuja função seria desviar a água do rio Xingu até a casa de força Kararaô ${ }^{6}$. A hidrelétrica de Kararaô produziria $11.000 \mathrm{MW}$, que representa alta produção de energia, mas que sua eletricidade seria levada através de linhão até o sul do país para uso das fábricas de São Paulo e Rio de Janeiro. A Hidrelétrica de Belo Monte movimenta e/ou mobiliza um número acentuado de trabalhadores migrantes cujos fatores primordiais desta migração são apontados por muitos estudiosos (SCHAAN; BEZERRA NETO; ALENCAR; SARGES, 2010) como os fatores de ordem econômica, que mobilizam força de trabalho diferenciada, mas sem condições efetivas de desenvolvimento regional, como se pode observar através dos grandes projetos implantados na Amazônia. As pessoas se sentem atraídas por oportunidades de trabalho ou terra para cultivar. A política implantada tanto pelos governos militares como pelos governos ditos de esquerda não modificam as políticas que atendem esta força de trabalho migrante, pois continuam desengavetando projetos da época do governo militar que favorecem os grandes deslocamentos de força de trabalho.

\section{RESULTADOS E DISCUSSÕES}

\subsection{DISCURSOS E PRÁTICAS SOBRE O "NOVO" E O "VELHO" DESENVOLVIMENTO E PROGRESSO}

Cheguei em Altamira por volta de quinze horas, numa tarde muito quente, na segundafeira santa. ${ }^{7}$ Já no caminho da cidade indaguei ao motorista o porquê da grande fileira em frente ao prédio todo azul? Em resposta ele mencionou: hoje é dia de pagamento dos peões que vão fazer à hidrelétrica. Novamente olhei um lugar sem cobertura, o sol fervendo e os trabalhadores com macacões de cinza claro, ou cor de terra preta misturada com areia. A cidade estava bastante barulhenta, com o trânsito intenso de carros, motos e muitos homens. Em busca de posicionamentos sobre a situação inicial em que se encontrava Altamira, em plena Semana Santa, no período de abril de 2012, cheguei, enfim, nesta cidade. Ao chegarmos ao endereço, o motorista perguntou meu nome, de onde eu vinha e se estavam me esperando. Anunciou minha chegada, o portão foi aberto e fui recebida com gentileza, mas com desconfiança por parte do segurança que fez questão de pegar minha pequena bagagem. Entendi depois a preocupação com a bagagem ${ }^{8}$. Além dele, mais dois homens em pé e duas mulheres estavam de cócoras descascando mandioca, em seguida, outra surgiu e foi me abraçar. ${ }^{9}$

\footnotetext{
${ }^{6} \mathrm{Na}$ língua Kaiapó significa um grito de guerra.

${ }^{7}$ Notas de Diário de Campo - abr./2012: Chegando em Altamira, ao pegar o táxi da vez perguntei ao motorista: Tem muita gente aqui mesmo como estão falando por ai? Não! Moça tem mais do que estão falando! Muito mais! Você vai pra onde? Para a casa do bispo. Neste endereço. Casa do bispo! Onde é a casa do bispo? Perguntou a outro motorista. É a casa de D. Erwin, a Praça Mattias, está em construção, a entrada é pela lateral. O senhor não mora aqui? Moro, mas estou aqui há pouco tempo. Ele tá na praça há trinta (30) anos, eu estou há três (03) meses. O senhor é de onde? Sou de Uruará, passei no Concurso da Guarda de Trânsito aqui em Altamira, mas sou baiano. Faço um extra no táxi! É bom o extra? É [...] todo dia chega gente neste aeroporto! Dá pra ganhar um dinheirinho bom!

${ }^{8}$ Notas: Diário de Campo - abr./2012: A casa vive em um verdadeiro sistema interno de vigilância eletrônica alcançando a orla, a praça, ou seja, ao redor da Prelazia. É um sistema vivido por D. Erwin há oito (08) anos. Está ameaçado de morte pelas várias denúncias contra a exploração sexual de crianças e adolescentes, das crianças emasculadas, devastação da Amazônia e hidrelétrica de Belo Monte. Ao falar sobre o assunto diz que perdeu sua liberdade exterior, não pode mais caminhar na orla, caminha na casa rezando três (03) terços, não vai a festas de aniversários e casamentos, pois sempre tem que levar mais duas (02) bocas.

${ }^{9}$ Notas: Diário de Campo - abr./2012: Você é Tânia? Sim! D. Erwin me falou de você. Fez boa viagem? Meu nome é França. Está muito quente! Agora, mas mais tarde é chuva. Preparei o quarto, para uma pessoa, ele me disse que você viria sozinha. Eu levo as suas coisas. Você não quer logo falar com ele? O que a senhora me diz?
} 
Os diálogos nas notas de rodapé nos dão a noção da acolhida por parte da Igreja, dos encaminhamentos para viabilizar a pesquisa e do interesse em apresentar suas ideias em relação às suas exposições contrárias à construção da Hidrelétrica de Belo Monte, a opinião nada contrária a energia limpa e sobre o desenvolvimento e progresso do país. A Prelazia do Xingu se manifesta em favor dos ribeirinhos, dos indígenas e populações que necessitem de seu acompanhamento. São concepções amadurecidas, coerentes e consistentes com os princípios e os valores humanistas da Igreja Católica. É a conversão pela convivência e o modo simples de viver o Evangelho.

$\mathrm{Na}$ oportunidade da semana - momento em que os cristão estavam em sintonia com o período considerado santo - foi, então, possível verificar os posicionamentos favoráveis ou contrários de outras Igrejas. No decorrer da pesquisa, a coleta nas igrejas - Igreja do Evangelho Quadrangular (IEQ), Igreja Universal do Reino de Deus (IURD) e Assembleia de Deus (AD) - a abordagem foi um pouco mais complicada, porém, seguindo os passos de Malinowski (1990), não ficar esperando e procurar buscando informações em outros espaços, mesmo que pareçam inacessíveis, ou ainda, "buscar o dados e isolar e relacionar uns com os outros e compreender pela qual eles se integram" (MALINOWSKI, 1990, vol. I, p. 317 apud FERNANDES, 2011, p. 121) foi necessário e importante para a pesquisa abordar oportunamente e entrevistar neste período sagrado para os cristãos que é a Semana Santa. Após várias tentativas e com muito custo conversei e consegui as entrevistas, ressalta-se que tudo eles falaram utilizando meias palavras, pois estavam sem a autorização do pastor.

Não há técnicas para estreitar laços, mas a confiança adquirida para o relato dos fatos, em particular pela situação ${ }^{10}$ em que encontravam-se as lideranças do Movimento Xingu Vivo para Sempre e da Prelazia e também da própria comunidade no momento desta etapa da pesquisa, foi necessariamente importante. Pois, isso depende "do grau de interesse e o grau de intimidade podem combinar-se para aumentar ou diminuir o anonimato da experiência" (BERGER; LUCKMANN, 1985, p. 52), portanto, acredita-se que o viés escolhido por meio dos laços pastorais foram essenciais para compor o quadro orientado na pesquisa. Por isso, com as entrevistas autorizadas e gravadas para aprofundar a temática acerca da Igreja do Xingu, do Movimento Xingu Vivo para Sempre e da comunidade do Xingu, nos propomos analisar os dados coletados.

Ora tudo parecia rotineiro, ora as problemáticas pareciam para mim como fatos para as questões levantadas. "O tempo que encontro na realidade diária é continuo e finito" e ainda complementado quando é afirmado que o face a face o outro é plenamente real " [...] contudo, nenhuma outra forma de relacionamento social pode reproduzir a plenitude dos sintomas da subjetividade presentes na situação face a face". (BERGER; LUCKMANN, 1985, p. 45 e 47).

Para alguns setores da sociedade e, principalmente, para os governos federal e estadual a inserção de grandes projetos de infraestrutura na região amazônica representa efetivamente desenvolvimento para a região. Esta percepção, como visto anteriormente, é hegemônica, mas

São $15 \mathrm{~h}$ e sei que muitos padres têm a sua sesta até esse horário. D. Erwin tem, mas é uma sesta [cf. Dicionário de Português Online Michaelis: tempo de descanso após o almoço, à hora do maior calor] bem leve.

${ }^{10}$ No dia 2 de abril, o juiz estadual da comarca de Altamira, Wander Luís Bernardo, deferiu parcialmente uma ação do Consórcio Construtor Belo Monte (CCBM) contra o Movimento Xingu Vivo para Sempre, contra a coordenadora, Antonia Melo, e o jornalista, Ruy Spozati, e outras duas pessoas vinculadas a luta social em Altamira. O Juiz emitiu um mandado proibitório, em caráter liminar, impondo multa de até cem (100) mil reais caso os citados cometam "qualquer molesta* à posse" do consórcio ou ao exercício das atividades dos trabalhadores ou ainda impeçam seu acesso aos canteiros. A liminar acusava o Movimento de incentivo à Greve dos trabalhadores da obra. A liminar saiu para os três líderes, mas, no momento da greve, somente o jornalista do MXVPS estava cobrindo o evento. Várias reuniões estavam acontecendo ao mesmo tempo com os advogados da Sociedade de Defesa dos Direitos Humanos (SDDH) que prestam serviços ao MXVPS. Em virtude desse fato, tivemos dificuldades para efetivação das entrevistas, que mesmo marcadas antecipadamente, foram adiadas e outras não realizadas como, por exemplo, no caso da representação do CIMI de Altamira. * [cf. Dicionário de Português Online Michaelis molestar significa: Enfadar, incomodar, importunar]. 
não é compartilhada por todos os grupos sociais, direta ou indiretamente, envolvidos nos conflitos daí decorrentes. Assim, formam-se dois blocos de discussões acerca de Belo Monte que enfatizam posicionamentos diversos sobre a vida e o processo de desenvolvimento e suas relações com o capital global.

\subsection{DOIS DISCURSOS: UM A FAVOR DA VIDA E OUTRO A FAVOR DO NEGÓCIO A QUALQUER PREÇO}

Por parte dos representantes da Igreja Católica e do Movimento Xingu Vivo para Sempre (MXVPS), suas propostas enfatizam a criação divina, as necessidades dos ribeirinhos, dos indígenas e a defesa da vida em abundância, assim como o seu significado centrado em "água boa, alimentação, escola, lazer, ambiente, tranquilidade". (ANTÔNIA MELO, ENTREVISTA CONCEDIDA À AUTORA, ABR., 2012). Dentro destas perspectivas de pensar as comunidades regionais, o processo de aceleração vislumbrado pelo paradigma da globalização está longe de atender as concepções de desenvolvimento e progresso almejadas por estes grupos.

As propostas encaminhadas pelo Estado tratam da realidade objetiva para direção da infraestrutura do território e compreendem o processo de uma organização social na qual se vende o trabalho, se arrenda a terra e se investe livremente o capital. Associado a este contexto, se organiza o poder político centralizado e monopolizado, separando a sociedade civil da gestão política que rege o território (HOUTART, 2011). Para Santos (1994), é uma tendência da globalização se consolidando com a lógica de extroversão e fragmentação do território.

Estado e Consórcio Belo Monte estão diretamente associados às formas de organização do capitalismo no processo atual da globalização que procura atender as novas tecnologias, sendo estas estendidas à base material de sua reprodução - a informática e a comunicação que dão, portanto, ao capitalismo uma dimensão realmente global, onde o sujeito passa a viver este processo assumindo a postura de um agente global. Neste contexto, a busca por novas fronteiras constitui um dos objetivos dos grandes consórcios e defensores da nova divisão social do trabalho e do modo de industrialização acelerado. A crise do capital financeiro e produtivo trazem novas frentes, tais como a agricultura camponesa - que deve ser convertida em uma agricultura produtivista -; os serviços públicos - os quais devem passar ao setor privado - e a biodiversidade, como base de novas fontes de energia e de matéria-prima. "O resultado é que agora todos os grupos humanos sem exceção, estão submetidos à lei do valor, mulheres, nativos, trabalhadores do campo e da cidade, mais uma vez o capitalismo enquanto projeto destrói as duas principais fontes de riqueza: a natureza e os seres humanos". (HOUTART, 2011, p. 422-424).

Os aspectos referentes à defesa da vida apontados pela Igreja e pelo MXVPS, os credenciam para difusão do projeto em favor da vida na região do Xingu. Estas ideias e debates sobre o desenvolvimento e progresso, na região amazônica, foram refletidas e incorporadas ao projeto com base em vários documentos produzidos pela hierarquia da Igreja Católica no Brasil e suas representações no regional. Esta compreensão é evidenciada abaixo com exatidão pelo Papa Paulo VI quando afirma que:

O desenvolvimento não se reduz a um simples crescimento econômico. Para ser autêntico, deve ser integral quer dizer, promover todos os homens e o homem todo, como justa e vincadamente sublinhou um eminente especialista, não aceitamos que o econômico se separe do humano; nem o desenvolvimento das civilizações em que ele se incluiu. O que conta para nós é o homem, até se chegar a humanidade inteira. (ENCÍCLICA POPULORUM PROGRESSIO (§ 14) 1967 apud RODRIGUES, 2010, p. 202). 
Desse modo, a perspectiva cristã de desenvolvimento está na preocupação de desenvolvimento humano integral, proferida pela Igreja como um desenvolvimento que deve ser "de todo o homem e do homem todo" no sentido de uma visão "humanista do ambientalísmo". (RODRIGUES, 2010, p. 201).

No período da pesquisa, o Instrumento de Coleta de Dados foi aplicado para diferentes grupos de atuação na Prelazia, assim como para outros que foram envolvidos na construção da hidrelétrica e moradores na área afetada pelo processo de Belo Monte; com base na técnica de entrevista realizada em Altamira. Este processo apresentou as perspectivas de lideranças da Igreja Católica, do MXVPS, bem como de outras Igrejas. Na época foi importante sentir a cidade, o movimento em plena situação de alvoroço, em vista dos primeiros dias de construção da Usina Hidrelétrica Belo Monte. Anterior ao início da construção, as opiniões estavam divididas entre a favor x contra a construção da hidrelétrica. A tabela a seguir, coletada no início da construção, acrescentou "agora sou contra, agora não tem jeito".

Tabela 2 - Perspectivas dos entrevistados da Igreja, Prelazia do Xingu, Movimento Xingu Vivo e Comunidade sobre a construção de Belo Monte

\begin{tabular}{|c|c|c|c|c|c|c|c|c|c|c|}
\hline \multirow{3}{*}{$\begin{array}{l}\text { Entrevista } \\
\text { dos/ } \\
\text { Opiniões } \\
\text { diversas }\end{array}$} & \multicolumn{8}{|c|}{ Quantidade } & \multirow{2}{*}{\multicolumn{2}{|c|}{ Total }} \\
\hline & \multicolumn{2}{|c|}{$\begin{array}{l}\text { Igrejas } \\
\text { (ieq/urd) }\end{array}$} & \multicolumn{2}{|c|}{ Prelazia do xingu } & \multicolumn{2}{|c|}{ Movimento xingu vivo } & \multicolumn{2}{|c|}{ omunidade } & & \\
\hline & bs. & $\%$ & bs. & $\%$ & bs. & $\%$ & bs. & $\%$ & bs. & $\%$ \\
\hline Contra & - & - & 4 & 2,2 & 2 & 1,1 & 2 & 1,1 & 8 & 44,0 \\
\hline A favor & 2 & 1,1 & - & - & - & - & 3 & 6,6 & 5 & 28,0 \\
\hline Não sabe & - & - & - & - & - & - & 1 & 5,5 & 1 & 6,0 \\
\hline Não tem jeito não & 1 & 5,5 & - & - & - & - & 1 & 5.5 & 2 & 11,0 \\
\hline Agora é contra* & - & - & - & - & - & - & 2 & 1,1 & 2 & 11,0 \\
\hline Total & 3 & 7,0 & 4 & 2,0 & 2 & 1,0 & 9 & $\mathbf{0 , 0}$ & 8 & 100,0 \\
\hline
\end{tabular}

Fonte: Pesquisa de campo. Entrevistas em Altamira. Abr./2012. Elaborado pela autora.

O sentido favorável dado a construção da hidrelétrica é a noção de progresso, "onde tem abelha tem barulho, por isso tem construção, onde tem barulho tem progresso" ou "quem tem dinheiro tem poder" "não adianta lutar".

Nós estamos há TEMPO ASSIM. Sem estrada. Ninguém passa no inverno e no tempo de sol é muito pó. O Jornal Nacional veio aqui e mostrou alguma coisa? Que nada. Mostraram o Canteiro? Mostraram nada, são da Rede Globo. Eles lá vão mostrar, eles são unha e carne com a CCBM, tem dinheiro, eles lá vão dizer o que povo tá passando. Vão nada. Mostrou a rodoviária, que tá cheia de gente atrás de trabalho. E só. Não mostram a verdadeira realidade. Sou a favor do progresso, esse início vai passar e aí teremos o progresso na região. (Entrevista em Altamira, abr./2012).

O tempo de referência é o investimento na transamazônica nas décadas de 1970-1980, no qual houve um acirramento da ocupação da Amazônia brasileira, incentivado pelo governo militar que via na ocupação deste "vazio demográfico", a possibilidade de garantir o domínio e a soberania nacional sobre a região, bem como a implementação de grandes projetos na perspectiva desenvolvimentista. Atualmente, o tempo de referência é outro, muito barulho e, assim, a comunidade se manifestou e se expressou em relação ao início de construção da Hidrelétrica de Belo Monte,

A cidade tá barulhenta, muito acidente, de carro, de moto. Não era assim muitos deram razão a Igreja Católica ou ao bispo "ele tem razão em defender a cidade, o meio ambiente, os índios". "Pois depois que a construtora chegou em Altamira há 
uma falta de respeito pelo trabalhador. As políticas básicas não estão sendo feitas como prometidas, um desastre social. Eu não concordo com Belo Monte. Eu não sei, mas não concordo. (Entrevista em Altamira, abr./2012).

"Onde tem barragem tem cheia". Sobre a resposta "não tem jeito não. Já tai”. Ou ainda "a gente não pode fazer nada, não adianta concordar ou discordar", ou "Eles têm dinheiro”. Quem disse que pobre tem vez. Minha Irmã tá difícil. A gente não queria. Mas tai. Mas a gente não concorda não. (Entrevista em Altamira, abr./2012).

As entrevistas acima e a seguir foram feitas de forma casual, andando pela cidade, na orla, nas igrejas, nas comunidades, durante as missas e procissões no período denominado pelos cristãos de Semana Santa.

Para os participantes da comunidade, na área da colônia e acima de 60 anos, as questões acerca do desenvolvimento envolvem as alterações na qualidade de vida na cidade, as mudanças no padrão habitacional, que se expressam no relato "[...] a cidade não dá valor a nada, agora vai ter desenvolvimento, muito no comércio, moradia, movimento grande. As colônias agora tem casa quando que nos vivia em barracas. Não tenho nada contra ao que traz desenvolvimento". (Entrevista em Altamira, abr./2012).

Os discursos mais elaborados dizem que Belo Monte é inviável, não se sustenta. Belo Monte "é um crime ambiental, um crime social ainda maior contra comunidades indefesas e um crime econômico-financeiro contra o país, que vai despender trilhões incluindo dinheiro público do Banco Nacional de Desenvolvimento (BNDES)". (SANSON, 2010, p. 2). É um processo, segundo alguns estudiosos, muito mais grave do que se imagina, pois está na raiz da tensão dos acontecimentos sociais e ambientais. É um modelo exógeno de exploração implantado na região à custa das riquezas das populações locais.

Discursos favoráveis a Belo Monte concordam com o desenvolvimento e o progresso, mas a cobrança pela infraestrutura da cidade afirma que tem que ser feita a Prefeitura, pois foi ela quem autorizou a construção de Belo Monte. Com ou sem autorização, Altamira e os estados nacionais, a partir da década de 1980, assumem o crescimento econômico e o progresso técnico como os únicos caminhos para garantir sustentabilidade. É um processo de ajustes institucionais, fiscais e jurídicos com incentivos para inovações, empreendedorismo e investimentos, com a capacidade de fornecer condições para um sistema eficiente de produção, circulação e distribuição de bens e serviços à população (SANSON, 2010). Assim, o país desenvolvido estaria no mesmo patamar de consumo de paises já desenvolvidos.

$\mathrm{Na}$ perspectiva do Discurso do Sujeito Coletivo (DSC), tem-se como análise a memória de um tempo considerado especialmente unitário para o fortalecimento das atividades que exigia um corpo de lideranças que caminhava em direção à resolução de situações de conflitos na região. Havia um opositor a cada tempo: o Estado brasileiro, a ditadura, o neoliberalismo. Durante a transição do regime autoritário para o democrático, nos anos 1980, o conjunto de representações da Igreja do Xingu atuou na Assembleia Constituinte em favor das emendas populares à Constituição e do combate à pobreza, onde seu foco de ação recaiu sobre a defesa da justiça social, da moral sexual tradicional e de uma crítica velada ao modelo neoliberal. 
Tabela 3 -Apoio recebido de entidades e grupos à Igreja e ao Movimento Xingu Vivo Para Sempre (MXVS) em resistência à construção da hidrelétrica de Belo Monte

Ideia central

E.1 A Igreja e o Xingu Vivo para Sempre - apoio financeiro, moral e logístico para as atividades muito mais de grupos de fora. Existe o nosso grupo, era muito mais forte quando todos estavam do mesmo lado inclusive o partido dos trabalhadores.

E.2 A história política do MXVS e da Igreja também mudou devido as estratégias do PT eles defendem a proposta do capitalismo ditatorial. Se machuca o capital eles reagem. Se já gastaram tanto dinheiro parar por quê? Então o brasileiro vale é o capital. E esse estupro do capital no ecossistema.

E.3 Os políticos dizem que é preciso ter barragem para desenvolver a região. Pergunte ao colono o que ele quer, ele vai responder: semente selecionada, assistência técnica, transporte, a segurança de que seu produto seja vendido, saúde, educação é isso que eles vão pedir.
Expressões chave

E. 1 Recebemos muito apoio. De muita gente do regional da CNBB, claro não de todos os bispos, no sentido de assinar, assinam, mas nós sabemos que alguns dizem não ter nada a ver com minha diocese. Apoio é para o bispo, mas fora do país e até de fora, mas temos apoio. Dos movimentos de dentro, nós estamos em torno dos que são tradicionais. $\mathrm{O}$ MAB, CIMI, GREN PEACE e outros...Os grupos envolta do povo do Xingu, são os que são diretamente atingidos pela barragem

E.2 Fizemos muitas lideranças inclusive as que estão hoje no PT. Que é a maior tristeza da minha vida uma grande decepção. Por isso, não queremos saber quem é de esquerda e quem e da direita. Se machuca o capital eles reagem. Se já gastaram tanto dinheiro parar por quê? Então o brasileiro vale é o capital. E esse estupro do capital no ecossistema. O governo não vale o cultural, os povos indígenas, aqui moram muitos. Vão acabar com a cultura, vão ser introjetados de outras culturas.

E.3 Altamira foi a primeira igreja ao Brasil a falar em ecologia, meio ambiente e desenvolvimento João XXIII chama a atenção para isso, mas aqui digo que o grande marco da Amazônia foi o documento de Santarém. Que deu o tom para a evangelização na Amazônia claro houve influência de em toda a América latina. A igreja tem o dever de ficar do lado dos pobres, dos excluídos, dos atingidos.

Fonte: Pesquisa de campo. Entrevistas em Altamira. Abr./2012. Elaborado pela autora.

Ao analisarmos os discursos da Prelazia do Xingu e o seu potencial em estabelecer questionamentos e resistências à construção da hidrelétrica de Belo Monte, observamos que a Igreja Católica em seu conjunto teve um papel fundamental na mudança na Região do Xingu. Defende-se, devido a estas evidências, que no processo de territorialização e desterritorializações formatou espaços, criou ambientes, se apropriou de identidades, de lutas, não somente para se manter plausível, mas também para sustentar a própria sobrevivência enquanto estrutura que se recria diante das transformações da sociedade.

A Amazônia, descrita sempre em números grandiosos e com muitos superlativos, oferece abundância de recursos florestais, minerais e hídricos que se tornou objeto de interesse nacional e internacional, entra na lógica do processo acentuado pela globalização onde o território brasileiro é visto como plataformas ofensivas da economia mundial ou de exportação, como sustentam alguns autores como Santos (2000) e Ianni (1997). Por estes fatores, entre outros, o território que corresponde a região amazônica brasileira, continuará sendo palco da grande teoria global de desenvolvimento aliado ao crescimento e progresso.

\section{CONSIDERAÇÕES FINAIS}

Hoje analisa-se que mesmo com a aliança de comunidades indígenas e tradicionais aliada a ambientalistas internacionais e se colocando em oposição a construção da barragem, mesmo com peregrinação das autoridades eclesiais junto aos órgãos competentes e assim fazer com que os olhos do mundo estivesse voltados para a região, é preciso entender que foi um insucesso, pois todos os danos previstos, tais como: Dezenas de milhares de indígenas e povos tradicionais foram forçados a abandonar suas casas e seu meio de subsistência, tal 
como a pesca. No centro da cidade de Altamira, após o período de fundação e efetivação da hidrelétrica, 50 mil trabalhadores abandonaram a cidade. Segundo o Instituto Nacional de Pesquisas Espaciais (INPE) em 2016, o desmatamento aumentou em 75\%. Segundo o Sistema de Alerta de Desmatamento (SAD/IMAZON, 2020), "Altamira registrou a maior área de desmatamento em toda a Amazônia Legal, totalizando 92km".

A indenização paga às comunidades indígenas durante a construção da barragem - até US\$ 10 mil por mês por aldeia indígena durante dois anos causou o reverso - a súbita explosão de dinheiro vivo estimulou uma corrida das comunidades rurais para adquirir bens de consumo e serviços modernos. Há vários processos judiciais contra a Norte Energia, acusando de destruição da cultura indígena.

A situação acima foi prevista pelos especialistas da área. Após o licenciamento para iniciar a construção da barragem, além das manifestações em vários lugares do país e fora dele e, na cidade de Altamira, aconteceram várias reuniões para discutir os itens reivindicatórios para o atendimento das demandas das comunidades que serão atingidas pela hidrelétrica.

Por outro lado, a Igreja e o Movimento Xingu Vivo para Sempre em suas demandas se mantiveram coerentes em seus projetos, compreenderam as mudanças latentes das questões ambientais, políticas, culturais, etc. e souberam ampliar suas articulações, associando, então, a luta local com as lutas da América Latina e do mundo. Dizemos não ser possível viver na atualidade sem que os novos paradigmas sejam impostos pela secularização, globalização e pós-modernismo. Hoje, as necessidades são imprescindíveis para as novas articulações, entendemos que o trabalho em rede viabiliza ações - moções que são pertencentes ao mundo - consoante, afirmam alguns estudiosos quando dizem que: "a extinção de espécies, de etnias, de símbolos, de línguas não pertence ao Xingu, mas a humanidade". (MAGALHAES, 2007, p. 129). No entanto, "apesar das redes, depois das redes, com as redes, há o espaço banal" (SANTOS, 1994, p. 16) o local, as especificidades, as identidades continuam presentes e em processo de mudança, muito mais no lugar, na casa, no lar. No entanto, "novos espíritos eclesiais" tanto para uma Igreja voltada para as soluções vindouras dos céus, como os novos espíritos com os 10 Mandamentos do Sínodo para a Amazônia.

São processos irreversíveis para os povos do Xingu, eles perderam sentimentos, paisagens, biodiversidade, funções climáticas, funções espirituais; no entanto enfatiza-se, não só a Amazônia, mas a humanidade perdeu esses valores.

\section{REFERÊNCIAS}

ACEVEDO, Rosa Marin. Visão histórica da região do rio Xingu: economia e diversidade étnica. PAPERS DO NAEA, Nº 276. Universidade Federal do Pará, Pará, 2010.

ANDRADE FILHO, Francisco Antônio. Igreja e ideologias na América Latina. Segundo Puebla. São Paulo: Ed. Paulinas, 1982.

ANDRADE, Manuel Correa. Territorialidade, desterritorialidade, novas territorialidades: os limites do poder nacional e do poder local. In: SANTOS, Milton; SOUZA, Maria Adélia A.; SILVEIRA, Maria Laura. (org.). Território Globalização e Fragmentação. São Paulo: Editora HUCITEC-ANPUR, 1994.

ASSOCIAÇÃO BRASILEIRA DE NORMAS TÉCNICAS. NBR 6022: informação e documentação - artigo em publicação periódica científica impressa - apresentação. Rio de Janeiro, 2003. 
AVANTARA, Anelise Montanes; VESCE, Gabriela Eyng Possolli. As representações sociais no discurso do sujeito coletivo no âmbito da pesquisa qualitativa. In: VIII CONGRESSO NACIONAL DE EDUCAÇÃO - EDUCERE e III CONGRESSO IBERO - AMERICANO SOBRE VIOLÊNCIAS NAS ESCOLAS - CIAVE, 2008, Paraná. Anais Eletrônicos. Paraná: PUC, 2008.

BERGER, Peter L.; LUCKMANN, Thomas. A construção social da realidade. Petrópolis, Rio de Janeiro: Vozes. 1985.

BOFF, Leonardo. Mística e Espiritualidade. $6^{a}$ ed., rev. e amp. Rio de Janeiro: Garamond, 2008.

CARA, Roberto Bustos. Territorialidade e identidade regional no sul da Província de Buenos Aires. In: SANTOS, Milton; SOUZA, Maria Adélia A.; SILVEIRA, Maria Laura. (org.). Território, Globalização e Fragmentação. São Paulo: Editora HUCITEC-ANPUR, 1994.

CONSELHO INDIGENISTA MISSIONÁRIO. [Relatório] Violência contra os Povos Indígenas no Brasil - dados de 2010. Localização: Arquivo CIMI/ Pará. ISSN 19847645. 2010. Disponível em: https://cimi.org.br/pub/relatorio/Relatorio-violencia-contra-povosindigenas_2010-Cimi.pdf. Acesso em: 30 abr. 2011.

FERNANDES, Florestan. Florestan Fernandes: Sociologia crítica e militante. In: IANNI, Octavio (org.). $2^{\mathrm{a}}$ ed. São Paulo: Expressão Popular, 2011.

FRAGOSO, Hugo. A era missionária (1686 -1759). In: HOORNAERT, Eduardo. (org.). História da Igreja na Amazônia. Petrópolis, RJ: Vozes, 1992. p. 139-209.

GRZYBOWSKI, Cândido. Belo Monte: Uma obra emblemática. Centro de Pesquisa e Apoio aos Trabalhadores - CEPAT. Curitiba, Paraná. Disponível em:

http:// www.ihu.unisinos.br/Instituto Humanitas Unisinos-IH. Acesso em: 30 abr. 2011.

HOUTART, François. Os movimentos sociais e a construção de um novo sujeito histórico. In: BORON, Atílio A.; AMADEO, Javier, GONZÁLEZ, Sabrina, (org.). A teoria marxista hoje problemas e perspectivas. São Paulo: Expressão Popular e. CLACSO Livros, 2006. (Coleção Campus Virtual).

IANNI, Octavio. Teorias da globalização. $4^{\mathrm{a}}$ ed. Rio de Janeiro: Civilização Brasileira, 1997.

IOKOI, Zilda Gricoli. Igreja e camponeses. Teologia da Libertação e Movimentos Sociais no campo Brasil e Peru 1864-1986. São Paulo: FAPESP - HUCITEC, 1996.

LEFÈVRE, et. al. $\mathrm{O}$ discurso do sujeito coletivo: uma nova metodologia em pesquisa qualitativa. Caxias do Sul, EDUCS, 2000.

LEFÈVRE, Fernando; LEFÈVRE, Ana Maria Cavalcanti. O sujeito coletivo que fala. Comunicação. Saúde, Educ. Interface (Botucatu) [online] USP, São Paulo, v, 10, n. 20, p. 517 - 524, jul./dez., 2006. Disponível em: https://doi.org/10.1590/S141432832006000200017. Acesso em: 30 abr. 2011. 
LITTLER, PAUL E. Territórios sociais e povos tradicionais no Brasil: por uma antropologia da territorialidade. Brasília: [s.n.], 2002, p. 2 - 23. (Série Antropologia).

MAGALHÃES, Sonia Maria Simões Barbosa. Lamento e dor: Uma análise sócio antropológica do deslocamento compulsório provocado pela construção de barragens. 2007. Tese (Doutorado em Ciências Sociais - Área de Concentração em Antropologia) - Programa de Pós-Graduação em Ciências Sociais da Universidade Federal do Pará em co-tutela com a École Doctorale Vivant et Sócietés da Universidade Paris 13. Belém, Pará, 2007.

MARTINS, José de Sousa. A chegada do estranho. (Prefácio). In: HEBETTE, Jean. O cerco está se fechando. (org.). Belém: NAEA/UFPA. 1991, p. 15-33.

MIRANDA, Tânia Nazarena de O. Igreja, território e poder: discursos e práticas em resistência à Belo Monte. 2013. Dissertação (Mestrado em Ciências da Religião) - Programa de Pós-Graduação em Ciências da Religião da Universidade do Estado do Pará. Belém, Pará, 2013.

PINTO, Lucio Flávio. A Amazônia em questão: Belo Monte, Vale e outros temas. São Paulo: B4 Editora, 2012.

PONTES, Felício; BELTRÃO, Jane. Xingu, Barragens e Nações Indígenas. In: SEVÁ, A. Osvaldo (org.). TENOTÃ-MÕ: alertas sobre as consequências dos projetos hidrelétricos no rio Xingu. São Paulo: International Rivers Networ, 2005.

PONTES, Felício. A Visão do MPF. Jornal Diário do Pará, Belém, 12 set. 2010, 31 out. 2010. Caderno Economia.

RODRIGUES, Edmilson Brito. Território e soberania na Globalização: Amazônia, jardim de águas sedento. 2010. Tese (Doutorado em Geografia) - Programa de Pós-Graduação em Geografia. Universidade de São Paulo - Faculdade de Filosofia e Letras e Ciências Humanas. São Paulo, 2010.

ROSENDAHL, Zeny. Território e territorialidade: uma perspectiva geográfica do estudo da religião. In: X Encontro de Geógrafos da América Latina, 2005, São Paulo. Anais.

Universidade de São Paulo. 2005. Disponível

em: http://observatoriogeograficoamericalatina.org.mx/egal10/Geografiasocioeconomica/Geo grafiacultural/38.pdf. Acesso em: 30 abr. 2011.

SANSON, Cesar. [Documento] Análise de Conjuntura - 2012. Localização: Centro de Pesquisa e Apoio aos Trabalhadores - CEPAT. Instituto Humanitas Unisinos - IHU, 2012.

SANTOS, Boaventura de Sousa. Os novos movimentos sociais. In: SANTOS, Boaventura de Sousa; SETUBAL, Mariana; LEHER, Roberto. (org.). Pensamento crítico e movimentos sociais: diálogos para uma nova práxis. São Paulo: Cortez, 2005 .

SANTOS, Milton. Território e sociedade. [Fevereiro, 2000]. Entrevistadores: Odete Seabra, Monica de Carvalho e José Correa Leite. Entrevista concedida a Fundação Perseu Abramo. São Paulo: Editora Fundação Perseu Abramo, 2000. 
SANTOS, Milton; SILVEIRA, Maria Laura. O Brasil: Território e sociedade no início do século XXI. 16ª ed., São Paulo: Rio de Janeiro: Editora Record, 1994.

SCHERER - WARREN, Ilse. Rede de movimentos Sociais. São Paulo: Edições Loyola, 1993.

KR ÄUTLER, Erwin. Os povos da Amazônia a e voz de seus pastores. Belém: CNBB Norte $2,2005$.

KRÄUTLER, Erwin. Servo de Cristo Jesus: memórias de luta e esperança. In: SUES, Paulo (org.) São Paulo: Paulinas, 2009.

UMBUZEIRO, Antônio. Altamira e sua história. 4ª ed. Belém: Ponto Press Ltda., 2012. 